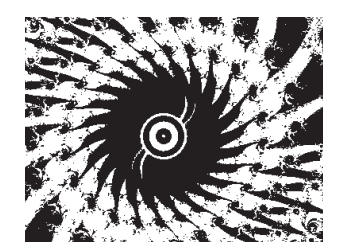

doi:10.5559/di.21.4.09

\title{
POLJOPRIVREDNA POLITIKA U RADOVIMA HRVATSKIH AUTORA 20. STOLJEĆA
}

Ramona FRANIĆ, Ornella MIKUŠ, Ivo GRGIĆ

Agronomski fakultet, Zagreb

UDK: 338.43(497.5)"19"

Pregledni rad

Primljeno: 15. 4. 2012.

Osnova za ovaj rad bila su uvodna poglavlja magistarskog rada "Agrarna politika u ruralnom razvitku Republike Hrvatske, s posebnim osvrtom na cjenovnu i poticainu politiku" Ramone Franić, obranjenog na Agronomskom fakultetu Sveučilišta u Zagrebu 22. prosinca 1994. i doktorske disertacije "Ocjenjivanje ruralne konkurentnosti kao podloga kreiranja politike ruralnog razvoja", Ornelle Mikuš, obranjene na Agronomskom fakultetu Sveučilišta u Zagrebu 28. siječnja 2010. godine.

Očekivani ulazak Hrvatske u Europsku uniju iznova aktualizira spremnost naših poljoprivrednih proizvođača na tržnu utakmicu koja ih uskoro očekuje. U tome se propitkuju ciljevi i popratne mjere dosadašnje poljoprivredne politike, ali i njezin razvoj u smjeru brige o cjelokupnom ruralnom prostoru u suglasju s evolucijom Zajedničke poljoprivredne politike EU-a. Dosadašnje društveno-ekonomske promjene nisu značajnije promijenile glavne ciljeve poljoprivredne politike (osiguranje dovoljno hrane za potrošače po razumnim cijenama te ravnopravan životni standard poljoprivrednika), nego su se samo mijenjali instrumenti i mjere država s obzirom na ekonomske uvjete i političke okolnosti. U Hrvatskoj stručnoj literaturi položaj poljoprivrednika i život u seoskim sredinama podrobnije se istražuje od sredine 19. stoljeća. Rezultati mnogih istraživanja, a posebno izrečene preporuke, aktualni su i danas. Već zarana se u mnogim radovima upozorava na razloge različitoga položaja poljoprivrednika u pojedinim državama, a u radovima potkraj 20. stoljeća ističe se nemogućnost preslikavanja pojedinih rješenja iz EU-a na hrvatske prilike.

Ključne riječi: država, selo, poljoprivreda, poljoprivredna politika, Hrvatska

$\triangle$ Ramona Franić, Agronomski fakultet Sveučilišta u Zagrebu, Zavod za agrarnu ekonomiku i ruralni razvoj, Svetošimunska cesta 25, 10000 Zagreb, Hrvatska.

E-mail: ramonaf@agr.hr

\section{UVOD}

$\mathrm{U}$ svjetlu aktualnih rasprava o smislu državne intervencije $u$ gospodarstvu i učincima te intervencije na ekonomske rezultate i motivaciju za rad, osobito u uvjetima ekonomske krize (World Bank, 2009.), u Hrvatskoj se intenzivira pitanje uloge 
DRUŠ. ISTRAŽ. ZAGREB GOD. 21 (2012),

BR. $4(118)$

STR. 989-1006

FRANIĆ, R., MIKUŠ, O., GRGIĆ, I.:

POLJOPRIVREDNA... državne politike u razvoju poljoprivrede i seoskoga prostora, u kojemu živi gotovo polovina stanovništva države. Rasprava o poljoprivredi postaje glasnija osobito $\mathrm{u}$ razdoblju neposredno prije ulaska u EU, usklađivanja proizvodnih, ekonomskih i političkih standarda, a potom i seljačkih prosvjeda i ograničenih proračunskih sredstava za udovoljavanje njihovim očekivanjima.

Tradicionalno se poljoprivreda doživljava isključivo kao djelatnost kojoj je osnovna funkcija proizvodnja hrane. Njezino se značenje i vrijednost stoga procjenjuju vrijednošću poljoprivrednih proizvoda, slično kao što se i vrijednost nekoga nacionalnog gospodarstva mjeri bruto domaćim proizvodom. Međutim, u zadnjim godinama raste spoznaja da poljoprivreda ima mnogo veću vrijednost od ove i da njezine višestruke funkcije osiguravaju brojne koristi, često spominjane kao "eksternalije". Uključuju sigurnost hrane, zaštitu okoliša, održavanje ruralnih tradicija i ruralnih zajednica, krajobrazne vrijednosti.

Bez obzira na suvremene proizvodno-tehnološke okolnosti koje poljoprivredu sve više pretvaraju u "industriju", državna intervencija u poljoprivredi je i dalje nužna i određena specifičnim društveno-ekonomskim i strateškim interesima, kao i specifičnim obilježjima same poljoprivrede. Država intervenira u ovom sektoru uglavnom iz tri razloga: relativno niskoga per capita dohotka od poljoprivrednih proizvoda (uzrokovanog niskom dohodovnom elastičnošću potražnje za hranom), nestabilnosti poljoprivrednih cijena i dohotka (uzrokovanih niskom elastičnošću ponude poljoprivrednih proizvoda) i, na kraju, strateškim ciljevima koji mogu obuhvaćati zadržavanje stanovnika u ruralnim područjima ili ostvarivanje zadovoljavajuće razine samodostatnosti u određenim poljoprivrednim proizvodima. Jednako kao što su i ove zakonitosti trajne, tako su i opći ciljevi djelovanja politike u poljoprivredi postojani i svode se na učinkovito omogućavanje sigurne, pouzdane i dovoljne ponude hrane za potrošače po razumnim cijenama, uz osiguravanje zadovoljavajućega i ravnopravnoga životnog standarda poljoprivrednicima. Razlikuju se samo instrumenti i mjere kojima se ciljevi mogu ostvariti, a njih država bira upravo s obzirom na suvremene ekonomske uvjete i političke okolnosti.

Da je tome tako, pokušat ćemo dokazati prikazom radova koji obuhvaćaju agrarno-političku problematiku u Hrvatskoj u proteklih više od stotinu godina. Bez ambicije ulaženja $\mathrm{u}$ duboke prosudbe društveno-političkih okolnosti i kritiziranje rezultata politika, osnovni je cilj rada, izdvajajući elemente poljoprivredne politike o kojima pišu autori radova, determinirati elemente sličnosti i razlika kroz povijest i ustanoviti postoji li kvalitativni pomak u razvoju ovih politika od prvih 
DRUŠ. ISTRAŽ. ZAGREB GOD. 21 (2012),

BR. 4 (118),

STR. 989-1006

FRANIĆ, R., MIKUŠ, O., GRGIĆ, I.:

POLJOPRIVREDNA. analiziranih izvora do danas. Pritom pod pojmom 'poljoprivredna politika' razumijevamo i odnos države prema selu i ruralnoj sredini, upravo kako je shvaća i Zajednička poljoprivredna politika EU-a.

Rad se temelji na pregledu i analizi povijesne literature iz domene poljoprivredne politike i odnosa države spram sela, a iz radova izlučujemo citate iz kojih se najjasnije sagledavaju trenutačne društveno-ekonomske okolnosti u kojima se kreira agrarna politika. Naglašavanjem ključnih misli citiranih autora želimo ustanoviti jesu li analitičari - osim terminologije - promijenili i žarište svojeg interesa. Zanima nas i jesu li donositelji agrarno-političkih odluka prihvaćali i primjenjivali njihove spoznaje kako bi se rezultati analiza primijenili u praksi.

\section{AGRARNA POLITIKA HRVATSKE OD DRUGE POLOVICE 19. STOLJEĆA DO II. SVJETSKOG RATA}

Osnovni postulati agrarne i ruralne politike zapisani su već u prvim agrarno-političkim analizama, a u ovom radu pratimo ih od druge polovice 19. stoljeća. To je razdoblje na području Hrvatske obilježeno snažnim tehnološkim, ekonomskim i društvenim zbivanjima, a u poljoprivredi velikom agrarnom krizom u zadnjoj četvrtini 19. stoljeća. Obrt se odvaja od poljoprivrede, a kapitalizam postupno zamjenjuje feudalne odnose. Iako $\mathrm{u}$ strukturi poljoprivrede prevladavaju sitna gospodarstva, veća gospodarstva nositelji su tehničkog razvoja, a poljoprivredna proizvodnja prisutna je na međunarodnom tržištu (Defilippis, 2005.).

Iako smo već dobro zakoračili u 21. stoljeće, ponekad upravo iznenađuje kako se u domeni poljoprivrede i poljoprivredne politike teme nisu bitno promijenile više od stoljeća. Tako se čini da se današnja strahovanja domaćih poljoprivrednika od ulaska u Europsku uniju i natjecanja sa zaštićenim europskim poljoprivrednicima mogu obrazložiti prilično davnim političkim okolnostima. Naime, još potkraj 19. stoljeća Vichodil postavlja temelje čvrstoga gospodarenja i upozorava na osnovna pitanja uprave (Vichodil, 1883., 45): "Tako imade državah, gdje su u krieposti jednaka prava za sve državljane; nu imade i takvih, gdje su se jošte uzdržala posebna prava i razne povlastice, uplivajuće na dohodak i vriednost gospodarskih objektah". On prikazuje vrste posjeda u državi i njihovo mjesto u političko-pravnim odnosima: "Kod prosuđivanja vrijednosti kojega gospodarskog objekta valja uvažavati i političke odnošaje one zemlje, u kojoj se dotični posjed nalazi. Za poljodjelca nije svejedno: da li je vlada jaka ili čvrsta, da li imade $\mathrm{u}$ narodu povjerenje, da li su financije uređene, da li državna politika zajamčuje narodno-gospodarski razvitak zemlje..." (Vichodil, 1883., 47). Vichodil u svojem djelu objaš- 
DRUŠ. ISTRAŽ. ZAGREB GOD. 21 (2012)

BR. $4(118)$

STR. 989-1006

FRANIĆ, R., MIKUŠ, O., GRGIĆ, I.:

POLJOPRIVREDNA... njava utjecaj prometa i trgovine na dohodak i vrijednost gospodarstva Thunenovom teorijom krugova, a tumači i druge instrumente ekonomske (i poljoprivredne) politike, koji su i danas aktualni: kupnju i zakup zemlje, dohodak, rentu i porez - mjere propisane državnim zakonima koje "...uplivaju na dohodak i vriednost gospodarskoga dobra" (Vichodil, 1883., 49). Nešto kasnije, 1915. godine (Vichodil, 1915., 1) zapisao je misao koja je zajednička i svim budućim istraživačima ovoga makroekonomskog područja rada: "...za privatno uređenje gospodarskoga rada brinu se sami vlasnici posjeda; nu težije je uređivati ukupno gospodarstvo u jednoj državi ili u pojedinim pokrajinama većih država. $U$ tu svrhu imade državna gospodarska uprava u naprednim zemljama posebne organe ili samostalne urede, kojima je opredjeljena zadaća, da uzdržavaju očevidnosti ne samo postojeće radne sile, nego da radnike tako organiziraju, da nje može svaki gospodar, ako ustreba na svoju korist u svako doba upotriebiti."

Dvadesetih godina 20. stoljeća Frangeš analizira preduvjete za uspješnu poljoprivrednu proizvodnju i konkretne "socijalno-agrarne politike i pravno stanje u zemlji" (Kraljevini SHS, Frangeš, 1920.). Konstatira da će agrarna reforma proširiti granice proizvodnje u smjeru "razrješenja kmetskog odnošaja", dok od ekonomskih općenitih prilika granice proizvodnje opredjeljuju poglavito dva čimbenika - kreditne prilike i prilike prodaje u trgovini, dakle zapravo cijene proizvoda. Pritom naglašava da cijene poljoprivrednih proizvoda rastu sporije od cijena poljoprivrednih potrepština, a $\mathrm{k}$ tome i "Država naprotiv otešćuje u upravo oskudnoj mjeri ovu tešku borbu naših gospodara sa konkurencijom svjetske pijace. Ona to čini u unutarnjem i vanjskom prometu sa gospodarskim proizvodima: $u$ tuzemstvu maksimiranjem cijena, prama inozemstvu pako izvoznim carinama" (Frangeš, 1920., 13). Misli da su ove mjere diskvalificirane i da ne bi trebale biti na snazi u mirnodopskim uvjetima slobodne trgovine. Ova svoja stajališta potvrđuje i kasnije (Frangeš, 1926., 3), govoreći kako "uzroci krize leže s jedne strane u prilikama države SHS, same, a s druge strane u prilikama svjetskog tržišta."

U to vrijeme Poštić razmišlja podjednako (Poštić, 1926.a, 3): "Promjene na našem državnom tržištu samo su odraz prilika na svjetskom tržištu". Već tada "u obrani od hiperprodukcije... utekle su se sve za redom evropske države različitim zaštitnim sredstvima naročito zaštitnim carinama" (Poštić, 1926.a, 5). On u svojim radovima analizira disparitet cijena poljoprivrednih i nepoljoprivrednih proizvoda, unutrašnju organizaciju gospodarstva, prihode, rashode i dohodak. Zaključuje da je (Poštić, 1926.b, 48): "nesrazmjer cijena uzrokovan prevaljivanjem različitih tereta na konzumenta." Nadalje dodaje (Poštić, 1926.b, 51): "Poljoprivrednik imade takodjer da snosi uvećane 
DRUŠ. ISTRAŽ. ZAGREB GOD. 21 (2012), BR. 4 (118),

STR. 989-1006

FRANIĆ, R., MIKUŠ, O., GRGIĆ, I.:

POLJOPRIVREDNA. poreske terete i izravne, kao i neizravne (carine, trošarinu i t. d.) ali on u najviše slučajeva ne može da prevaljuje ove terete na konsumente, budući mu cijenu njegovih proizvoda, odnosno cijenu, po kojoj se naplaćuje njegova radna snaga, odredjuje svjetsko, a ne lokalno tržište." Tvrdi da je, osim toga, položaj poljoprivrede "paraliziran nizom odredaba državne vlasti (rekvizicijom i sl.)" (Poštić, 1926.b, 52).

Potkraj 1930-ih godina stanje poljoprivrede na tlu Hrvatske nije zamjetnije promijenjeno. To čitamo i iz djela Rudolfa Bićanića, u kojima on razmatra agrarne krize u Hrvatskoj (Bićanić, 1937., 12): "Država, državna vlast ili vladajući sloj u državi imao je kao glavni svoj cilj ekonomske politike: urediti zemlju 'po uzoru Evrope'...trebalo je zemlji dati modernu administraciju (t. j. građansku hrvatsku upravu)...Zbog toga su uvećavani porezi ubrzanim tempom...Narodni je novčani dohodak naglo padao, a porezi su ipak rasli. Tako su zahvaćali procentualno sve veći dio narodnog dohotka. Tako je seljak, da dođe do novca za porez, morao prodavati sve više svojih proizvoda. Uslijed toga je ulazio u novčani promet, sa svim posljedicama." U analizi cijena i pariteta domaćih i svjetskih cijena te poljoprivrednih i nepoljoprivrednih proizvoda kaže za cijene (Bićanić, 1939., 13): "One su niske kad seljak prodaje svoje proizvode, a visoke kad ih kupuje." Ujedno kritizira gospodarsku politiku koja uređuje carine u korist trgovine i industrije, a ne štiti poljoprivredu (Bićanić, 1939.).

\section{POLJOPRIVREDNA POLITIKA HRVATSKE OD II. SVJETSKOG RATA DO OSAMOSTALJENJA}

\begin{tabular}{l}
\hline Iz II. svjetskog rata Hrvatska u sklopu Jugoslavije izlazi kao \\
pretežno agrarna zemlja u kojoj poljoprivreda, unatoč vrlo \\
oštećenim resursima, otprilike sa 30\% pridonosi ukupnom \\
društvenom proizvodu (Defilippis, 2005.). Prihvaćen koncept \\
socijalističkoga društvenog i ekonomskog razvoja rezultira \\
pokušajima rješavanja agrarnoga i seljačkoga pitanja dvama \\
krugovima agrarnih reformi (1945. i 1953. godine), kojima se \\
raspodjeljuje zemljišni fond prema razvoju "društvenog vlas- \\
ništva". \\
U to doba Mijo Mirković svoja istraživanja i znanja s po- \\
dručja poljoprivredne proizvodnje i ekonomike objavljuje u \\
udžbenicima. On tumači ekonomiku agrara (Mirković, 1950.a) \\
i uvjete za povećanje proizvodnosti rada u poljoprivredi (je- \\
dan od načina jesu i administrativno-porezne mjere). Nakon \\
Drugoga svjetskog rata aktualno je pitanje stvaranja novih od- \\
nosa u agraru i stabiliziranje novih tipova "socijalističkih po- \\
ljoprivrednih poduzeća izraslih iz specifičnih prirodnih i his- \\
torijskih uvjeta poljoprivredne proizvodnje u FNRJ-i" (Mir- \\
ković, 1950.b, 60). Međutim, s jednakom pažnjom Mirković
\end{tabular}


DRUŠ. ISTRAŽ. ZAGREB GOD. 21 (2012)

BR. $4(118)$

STR. 989-1006

FRANIĆ, R., MIKUŠ, O. GRGIĆ, I.:

POLJOPRIVREDNA... proučava i detaljno opisuje položaj seljaka na našim prostorima od početka 20. stoljeća i ponašanje države spram malih posjeda (Mirković, 1952.). Uočava njihove probleme, zanemarivanje njihovih interesa i potreba i uspoređuje ih s položajem seljaka u razvijenim kapitalističkim zemljama, koje, upravo suprotno, izdvajaju velika sredstva za pomoć poljoprivredi (reguliranje i kontrola tržišta zajamčenim i minimalnim cijenama, kontingentima, preuzimanjem poreznih obveza).

U poratnom razdoblju država je postavila sebi zadaću reorganizirati i stvoriti novi sustav agrarno-političkih mjera, jer do 1941. godine "nije postojao, pa se prema tome nije ni mogao izvoditi neki određeni program poljoprivredne politike" (Mirković, 1968., 343). "Sve bitne mjere poduzete u oblasti poljoprivredne politike od 1918. do 1941. mogu se svesti na ova tri pitanja: agrarna reforma, razduženje poljoprivrednika i poljoprivredni kredit" (Mirković, 1968., 345). Sustavno se zanemarivanje poljoprivrede $u$ ukupnom gospodarskom razvitku nastavilo, iako agrarni ekonomisti, znanstvenici i političari razrađuju novi sustav "podruštvljavanja" sela i poljoprivrede u cilju općega društvenog razvoja. Napisano je mnogo radova ideološke prirode u kojima se obrazlagala i potvrđivala politika podrške društvenim gospodarstvima, bez poštovanja ekonomskih specifičnosti i socijalnih potreba seljaka.

Konkretnija zapažanja poteškoća u razvoju poljoprivredne proizvodnje i tržišta, kao i agrarne politike, daje Stipetić, pronalazeći zajedničke značajke sa svjetskom poljoprivredom (Stipetić, 1964., 10): "Agrarne politike mnogih kapitalističkih zemalja tokom velike svjetske krize (1925-1938) spoznale su da je reguliranje tržišta i cijena poljoprivrednih proizvoda jedno od najmoćnijih sredstava agrarne politike. Prvi i nesigurni pokušaji državne intervencije na tržištu poljoprivrednih proizvoda u tridesetim godinama, koji su se nadovezivali na još stariji agrarni protekcionizam zemalja zapadne Evrope, postepeno su prerasli u široki, sveobuhvatni sistem državnokapitalističkih mjera na tržištu poljoprivrednih proizvoda u privredno razvijenim kapitalističkim zemljama." On, na temelju ovih zapažanja, potvrđuje da država mora prema domaćoj poljoprivrednoj proizvodnji razviti specifičan zaštitni odnos. Objašnjava osnovne zaštitne politike: način formiranja cijena poljoprivrednih proizvoda i njihovo djelovanje na poljoprivrednu proizvodnju i potrošnju poljoprivrednih proizvoda, paritete cijena i njihove varijacije, kao i sustav državnoga podržavanja cijena kod nas premijama i regresima, iako su ove mjere usmjerene samo na "društvena gospodarstva" (Stipetić, 1964.). U mjere "direktne državne intervencije" (Stipetić, 1973.) ubraja kontrolu cijena maksimiranjem i zamrzavanjem, porez na promet i proizvodnju, carine i porez na do- 
DRUŠ. ISTRAŽ. ZAGREB GOD. 21 (2012), BR. $4(118)$

STR. 989-1006

FRANIĆ, R., MIKUŠ, O., GRGIĆ, I.:

POLJOPRIVREDNA... hodak. Poticanje izvoza i politiku uvoza (restrikcije ili olakšice) ubraja $u$ indirektnu državnu intervenciju. Odabir mjera agrarne politike uvijek je podređen "osnovnom 'strategijskom' interesu određena razdoblja, pri čemu se pojedinačni, parcijalni interesi moraju podrediti izabranom osnovnom cilju društva" (Stipetić, 1975., 275).

Pitanja cjenovne i subvencijske politike u svijetu, a osobito u Hrvatskoj, objašnjava Štancl. On 1960-ih godina ispituje utjecaj cijena, premija i regresa na poljoprivrednu proizvodnju odabranih gospodarstava. Rezultati istraživanja dokazali su (Štancl, 1964., 30): "postojeća politika premija i regresa utjecala je na strukturu proizvodnje i kroz to na akumulativnost pojedinih gospodarstava." Uočava da se nejednaki ekonomski uvjeti, koji vladaju u pojedinim proizvodnjama, odražavaju na strukturu proizvodnje i iskorištenje kapaciteta. Stoga predlaže uspostavljanje sustava praćenja troškova, dohotka, ponude i potražnje poljoprivrednih proizvoda na osnovi podataka odgovarajućega broja društvenih i privatnih gospodarstava širom zemlje, jer je to osnova za donošenje važnijih odluka u agrarnoj politici, poglavito u domeni cijena.

Podlogu istraživanju problematike suvremene državne intervencije u poljoprivredi Hrvatske osiguravaju i radovi novijega datuma. Na početku 1990-ih godina temeljitiju analizu agrarne politike radi Žimbrek sa suradnicima (Žimbrek, 1994.; Zimbrek i sur. 1994.), s naglaskom na politici cijena i subvencija, identificirajući osnovne tendencije, ciljeve i upotrijebljene instrumente agrarne politike u Hrvatskoj. Grahovac u svojim radovima analizira i opisuje hrvatsku agrarnu politiku, njezine ciljeve i mjere kroz duže razdoblje, kao i ulogu poljoprivrede u vanjskoj trgovini, razjašnjavajući pitanja konkurentnosti domaće poljoprivrede na svjetskom tržištu (Grahovac, 1988., 1992.), a istraživanja se nastavljaju u nastojanju da se, prema zahtjevima svjetskih političkih standarda i integracijskih procesa, izmjere učinci domaće poljoprivredne politike (Franić, 2000.).

\section{IZUČAVANJE RURALNOGA RAZVOJA U HRVATSKOJ}

Unatrag dvadesetak godina, a osobito otkako se Hrvatska strateški opredijelila za članstvo u Europskoj uniji, pa time i za prihvaćanje standarda Zajedničke poljoprivredne politike, mnogo se govori i djeluje na uvođenju koncepta ruralnoga razvoja u klasične obrasce poljoprivredne politike. Međutim, je li to baš "novi" koncept u domeni istraživanja agrarne politike i seoske sredine u Hrvatskoj? Istraživanja pokazuju (Mikuš, 2010.) kako su seljak, selo i poljoprivreda - kao pretežita djelatnost u selu - bili u povijesti česta tema rasprava među istraživači- 
DRUŠ. ISTRAŽ. ZAGREB GOD. 21 (2012) BR. $4(118)$

STR. 989-1006

FRANIĆ, R., MIKUŠ, O., GRGIĆ, I.:

POLJOPRIVREDNA... grarni ekonomisti ostavljaju nam u nasljeđe opsežnu literaturu o hrvatskom seljaštvu, načinu života na selu, vrijednostima i seoskoj tradiciji.

Osobito su vrijedna "istraživanja iz prve ruke", koja su znanstvenici provodili putujući po selima, obavljajući ankete ili intervjue sa stanovništvom, pa čak i živeći sa seljacima određeno vrijeme. Jedan od takvih prvih istraživača hrvatskoga sela, koji se zalagao za empirijsko proučavanje seljaštva, bio je pravnik Bogišić. On sastavlja poznati Naputak za opisivanje pravnijeh običaja, koji živu u narodu (Bogišić, 1867.), prvi anketni upitnik za proučavanje seoskoga života u nas. Smatra da za prikupljanje građe o seljaštvu '...ne bi trebalo prevrtati prašljive hartije ni sidjeti $u$ dušljivim arcivima, nego zaći $u$ najbliže selo' (citirano prema Puljiz, 1996., II). U nastojanju da njegovo istraživanje sela rezultira što vjerodostojnijim prikazom stanja na selu, sastavljeni upitnik uputio je svećenicima, učiteljima i drugim obrazovanim ljudima na selu kako bi prikupili raznovrsne podatke o životu seoskoga stanovništva.

U istom razdoblju, u drugoj polovici 19. stoljeća i na početku 20. stoljeća, osnivač Hrvatske pučke seljačke stranke, A. Radić, svoja istraživanja također usmjerava na kulturu i moralne vrijednosti sela. U svojim radovima upozorava na izrabljivanje seljaka od gospode, a seljaštvo jedino predstavlja pravu snagu koja može pokrenuti reformu društva, donijeti pravdu i napredak (Puljiz, 1996.). Radi proučavanja narodnoga života i Radić sastavlja jednu vrstu upitnika pod nazivom Osnova za sabiranje i proučavanje građe o narodnom životu (Radić, 1897.), u kojem donosi pitanja koja smatra važnima za opisivanje stanja na seoskom području.

$\mathrm{S}$ obzirom na to da se $\mathrm{u}$ to vrijeme počela buditi hrvatska nacionalna svijest, formirao se nacionalni politički pokret okrenut prema narodu i patriotizmu, nastajale su temeljne kulturne, obrazovne i znanstvene institucije i seljaštvo je došlo $u$ središte pozornosti. Tako tradiciju proučavanja hrvatskoga seljaštva i politički angažman u Hrvatskoj seljačkoj stranci nastavlja Bićanić. Kao član ravnateljstva Gospodarske sloge (od 1936. godine), sa svojim suradnicima osniva Zavod za proučavanje seljačkog i narodnog gospodarstva, preteču Ekonomskog instituta u Zagrebu. Namjerom da javnosti predoči život seljaka uputio se u najnerazvijenije krajeve Hrvatske: Liku, Dalmatinsku zagoru te zapadnu Bosnu i Hercegovinu.

Iz toga razdoblja nastala je knjiga (Bićanić, 1936.) u kojoj detaljno opisuje život i običaje seljaka i predlaže da seljak unaprijedi svoje gospodarstvo, prevlada stanje socijalne i političke nemoći u kojoj živi te da zauzme aktivnu poziciju u kapitalističkom društvu i ekonomiji. Osim u toj knjizi i brojnim radovima, proširuje svoja znanstvena zapažanja kroz kon- 
DRUŠ. ISTRAŽ. ZAGREB GOD. 21 (2012), BR. $4(118)$

STR. 989-1006

FRANIĆ, R., MIKUŠ, O., GRGIĆ, I.: POLJOPRIVREDNA. cept "Gospodarske sloge", namjera koje je poticati prosvjećivanje naroda i unapređenje seoskoga gospodarstva nizom promjena kako bi se poboljšala proizvodnost rada i konkurentnost seljačkih proizvoda (Puljiz, 1996.). Ističe i potrebu ekonomskog i političkog organiziranja seljaštva u zadruge ili sindikate.

Potrebu objašnjenja načina gospodarenja koji bi pridonio napretku hrvatskoga sela prepoznaje i Predavec, koji piše o narodnom gospodarstvu i definira važne pojmove s područja agroekonomike. Pojam gospodariti objašnjava kao: "Gospodariti znači ići za tim da se uz što manje truda i troška postigne neko dobro" (Predavec, 1909., 4). U istoj literaturi na način svojstven onom vremenu govori o proizvodnji, radu, produktivnosti rada i opisuje natjecanje ili utakmicu: "Kad vidim, da moj susjed radi istu stvar, koju hoće da proda, kao i ja, onda ću ja nastojati da ta moja stvar, taj moj proizvod bude bolji i jevtiniji. I to se zove utakmica ili natjecanje" (Predavec, 1909., 13).

Navedeni istraživači u tom vremenu samo su neki od brojnih (djelovali su i Dragutin Lambl, Gustav Vichodil, Otto pl. Frangeš i drugi). Njihovi radovi uglavnom se odnose na opise teškoga života seljaka. Međutim, ima i primjera dobroga gospodarenja u trgovini i poljoprivredi koji sežu još u 13 . stoljeće. Tako Roller (1995.) prikazuje agrarno-proizvodne odnose od 13. do 15. stoljeća. On ističe kako je poljoprivreda bila vrlo dobro organizirana i pridonosila boljitku čitavoga gospodarstva u ondašnjoj Dubrovačkoj Republici. Ciljevi Dubrovačke Republike bili su usmjereni jačanju blagostanja i moći grada, stoga su u poljoprivredi stvoreni odnosi koji predstavljaju "...našu specifičnost, predstavljaju odnose, koji su ponekad toliko napredniji od agrarnih odnosa toga vremena u tuđim zemljama, pa i u ostalim našim krajevima" (Roller, 1955., 266).

Ruralni sociolozi današnjega vremena nastavljaju istraživati društvene odnose na selu, selo kao prostor života i rada i seljačke obitelji. S obzirom na to da se 1990-ih godina u Europi sve više počinje govoriti o cjelokupnom razvitku ruralnoga prostora, a ne samo poljoprivrede koja je dotad bila gotovo sinonim za selo, takve se ideje šire i kod nas. Tako Defilippis govori o nužnosti integralnoga pristupa razvitku ruralnoga prostora, što podrazumijeva gospodarski, socijalni i kulturni napredak jednoga prostora $\mathrm{i}$ zajednice koja $\mathrm{u}$ tom prostoru živi, uključujući i očuvanje i unapređenje prirodne okoline (Defilippis, 1993.). Također ističe poteškoće koje se javljaju, jer se upravljanje integralnim razvitkom sela ne može rješavati monosektorskim pristupom (uglavnom poljoprivredom), nego je nužan pristup koji, osim međusektorske suradnje, sve više zahtijeva usuglašavanje stavova, odluka i akcija 
DRUŠ. ISTRAŽ. ZAGREB GOD. 21 (2012)

BR. $4(118)$

STR. 989-1006

FRANIĆ, R., MIKUŠ, O., GRGIĆ, I.:

POLJOPRIVREDNA... na svim razinama upravljanja (lokalnoj, regionalnoj, državnoj).

Općenito, u procesu približavanja zapadnoeuropskim društvenim, političkim, gospodarskim i kulturnim standardima, tj. modernizaciji, društvo se susreće s pozitivnim i negativnim posljedicama za ruralno društvo. U tom kontekstu Cifrić izučava odnos društva prema okolišu. Uzimajući u obzir dugoročnost i održivost ruralnoga razvoja, ističe potrebu ponovnoga definiranja društvenih odnosa prema okolišu i upozorava da okoliš ne smije biti više 'ničije dobro', tj. opće dobro, koje se može bezobzirno iskorištavati za čovjekove interese i potrebe (Cifrić, 1993.). U svojoj knjizi, deset godina kasnije, detaljno razrađuje problem ruralnoga razvoja u kontekstu modernizacije sela i poljoprivrede koja sa sobom nosi negativne posljedice za okoliš (Cifrić, 2003.).

Modernizaciju sela istražuju i Štambuk i suradnici. Autori tvrde da modernizacija, $\mathrm{s}$ jedne strane, nosi izazove očuvanja ruralnih posebnosti izraslih u okviru lokalnih i nacionalnih tradicija, a, s druge, poboljšanje ukupne kvalitete života, obrazovanosti, kulture i materijalnog standarda (Štambuk i sur., 2002.). Istražujući hrvatsko selo, ističu između osta$\log$ i potrebu kvalitetnije organizacije institucionalne i financijske pomoći koja bi osnažila položaj lokalne samouprave i tako povećala njihov utjecaj i odgovornost za smjer i intenzitet razvojnih procesa. Stambuk nadalje opisuje agrarnu politiku kao dio ruralne politike i prikazuje faze stvaranja Zajedničke poljoprivredne politike (ZPP), koja uključuje razvoj koji se ne oslanja više samo na poljoprivredu. Djelomično opisuje i primjenu ZPP-a u zemljama članicama EU-a, iskustva kojih mogu poslužiti i za razvojne perspektive hrvatskoga sela (Štambuk, 2002.).

Navedeni i ostali autori svojim istraživanjima i radovima također godinama upozoravaju na loše ekonomsko stanje, nepovoljnu obrazovnu strukturu, na devitaliziranje i opadanje broja stanovnika u ruralnim područjima, koji je u nekim krajevima tako drastičan da čitava sela jednostavno nestaju (Puljiz, 1993. i Pokos, 2002.). Brkić i Žutinić analiziraju sociodemografske promjene u seoskim naseljima u Hrvatskoj od 1991. do 2001. godine i iskustva u zemljama Europske unije u razvoju seoskoga područja, gdje su rješenja za razvoj ruralnih područja išla prema udjelu lokalnoga stanovništva, lokalnih vlasti, lokalnih poslovnih organizacija i seoskih institucija (Brkić i Žutinić, 2002.). Naglašavaju i primjenu holističkoga pristupa ruralnom razvitku, koji bi trebao zamijeniti sektorsku politiku.

Osim ruralnih sociologa i pravnika, današnji agrarni ekonomisti također pridaju važnost i sagledavanja života na selu sa svih aspekata, pri čemu je ekonomija samo jedna od sastavnica cjelokupnoga i održivoga ruralnog razvitka. U tom kon- 
DRUŠ. ISTRAŽ. ZAGREB GOD. 21 (2012), BR. $4(118)$

STR. 989-1006

FRANIĆ, R., MIKUŠ, O., GRGIĆ, I.:

POLJOPRIVREDNA. tekstu Franić i suradnici (2003.) naglašavaju da se u nastojanju postizanja održivoga ruralnog razvitka ekonomski rast ne može promatrati odvojeno, nego u skladu s ekološkim zahtjevima očuvanja okoliša, kao i koordinaciji ljudskih mogućnosti, prava i obveza. Autori analiziraju cjenovnu i subvencijsku politiku i uočavaju zaokret hrvatske agrarne politike prema modelu necjenovne podrške te predviđaju preoblikovanje strateških ciljeva i mjera agrarne politike prema strukturnoj potpori. Ističu da je primarni cilj poljoprivrednoga razvitka obično pojačan rast poljoprivredne proizvodnje, dok je cilj ruralnoga razvitka poboljšanje materijalnoga i društvenoga bogatstva ruralnoga stanovništva, a državna intervencija mora biti usmjerena na motivaciju poljoprivrednika da prihvate promjene koje će dovesti do toga poboljšanja. Nekoliko godina kasnije autori daju prikaz reformi Zajedničke poljoprivredne politike, naglasak koje je postupno presudio u korist osnaživanja mjera za ruralni razvoj. Hrvatska kao zemlja kandidatkinja za ulazak u EU prilagođava svoje zakonodavstvo, modele i brojne programe ruralnoga razvitka na lokalnim i državnoj razini prema europskim standardima (Franić, 2005., 2006.), pokušavajući kvantificirati učinke državnih politika u razvoju ruralnoga prostora (Kumrić i Franić, 2008.; Mikuš i sur., 2012.).

A da suvremeni istraživači poštuju sugestiju svojih davnih prethodnika, govore i rezultati novijih "istraživanja iz prve ruke". I danas se, kao i prije stoljeća, ustanovljuje kako su najveće poteškoće života u hrvatskom seoskom prostoru gospodarske naravi: manjak zaposlenja, slaba mogućnost izbora zanimanja i niže zarade $\mathrm{u}$ odnosu na zaposlenje $\mathrm{u}$ gradu. Grgić i suradnici (2011.a, 2011.b) u svojim radovima kreatore politika upozoravaju na pogubne posljedice daljnje depopulacije hrvatskoga sela, osobito preveliku urbanizaciju, neravnomjeran razvitak Hrvatske i nedovoljno iskorištenje prostornoga, proizvodnoga i ljudskoga potencijala. Istodobno predlažu da treba prihvatiti mišljenja žitelja ruralnih područja koji kao "prilike" zaustavljanja negativnih tendencija u ruralnim područjima ističu razvoj nepoljoprivrednih djelatnosti (Grgić i sur., 2011.c), i to posebno agroturizma (Grgić i sur., 2011.d).

\section{RASPRAVA I ZAKLJUČCI:}

\section{POSTOJE LI "SUVREMENA" AGRARNA I RURALNA POLITIKA?}

Europska Zajednička poljoprivredna politika u zadnja dva desetljeća doživljava osjetan zaokret u ciljevima i popratnim mjerama agrarne politike, i to prema izravnoj potpori poljoprivrednom dohotku i ruralnom razvoju. Hrvatska se poljoprivredna politika, zbog skoroga pristupa EU, ubrzano prilagođuje europskim standardima - ako nikako drugačije, a ono $u$ administrativnom smislu. Istodobno čini se da se cilje- 
DRUŠ. ISTRAŽ. ZAGREB GOD. 21 (2012)

BR. $4(118)$

STR. 989-1006

FRANIĆ, R., MIKUŠ, O., GRGIĆ, I.:

POLJOPRIVREDNA... vi istaknuti u domaćim agrarno-političkim dokumentima još ne ostvaruju u zadovoljavajućoj mjeri; nema velikog pomaka $\mathrm{u}$ ostvarivanju samodostatnosti u poljoprivrednim proizvodima, dohodak poljoprivrednika zaostaje za prosjekom, vanjsko-trgovinska bilanca je i dalje negativna, razlike između standarda ruralnog i urbanog stanovništva se intenziviraju. Sve se češće postavlja pitanje postoji li u nas dovoljno znanja i argumenata kojima bi se opravdalo i omogućilo prihvaćanje europskih standarda u hrvatsku poljoprivrednu praksu, kako bi se uklonile razlike između domaćih i europskih poljoprivrednika.

U procesu "postupne prilagodbe europskim standardima" kojiput se čini da postoji golem jaz između hrvatskih i europskih ciljeva poljoprivredne politike; za rješavanje hrvatskih problema danas više nisu na raspolaganju najpraktičniji instrumenti i mjere, a i institucionalni je okvir modificiran $u$ skladu sa strateškim ciljem ulaska Hrvatske u EU, a ne s ciljem rješavanja problema hrvatske poljoprivrede. Taj raskorak često se u praksi potvrđuje kao loša "copy-paste" metoda europskih standarda $u$ domaću politiku i često nema opravdanje u domaćoj poljoprivrednoj realnosti.

Ipak, osvrt na radove istraživača agrarne politike u proteklom stoljeću može prilično osvijetliti odgovore na ova pitanja. Tako Vichodil još od 1883. do 1915. godine piše o povlasticama koje uživaju poljoprivrednici u nekim zemljama i kvaliteti državne uprave kao o razlozima zbog kojih nisu u jednakom položaju poljoprivrednici u svim zemljama, već tada objašnjavajući uzroke zaostajanja hrvatskih poljoprivrednika $\mathrm{u}$ odnosu na visokosubvencionirane poljoprivrednike Europske zajednice u drugoj polovici 20. stoljeća.

Još uvijek u vrijeme prije formiranja Europske ekonomske zajednice, Frangeš i Poštić (Frangeš, 1926.; Poštić, 1926.a) analiziraju cjenovne paritete koji su na štetu poljoprivrednih proizvoda, ali, još važnije, utjecaj konkurencije svjetskoga tržišta, uočavajući kako je naše tržište odraz prilika na svjetskom tržištu. Ima li jasnijeg argumenta za današnje stanje u gospodarstvu općenito, pa tako i u poljoprivredi Hrvatske? Zato je gotovo nevjerojatno da se $\mathrm{u}$ istraživanju provedenom u nas na početku 21. stoljeća ustanovilo kako ispitanici - članovi uprava poljoprivrednih kombinata - ne misle da međunarodno tržišno okruženje utječe na poslovanje poduzeća kojima upravljaju (Franić i sur., 2004.). Jednako tako, Poštićev stav kako u mirnodopskim uvjetima svjetske trgovine nema osobito opravdanih razloga za snažnu državnu intervenciju i danas je aktualan u političkim promišljanjima, osobito kada smo na trgovinsku liberalizaciju pristali potpisivanjem međunarodnih trgovinskih ugovora. 
DRUŠ. ISTRAŽ. ZAGREB GOD. 21 (2012), BR. $4(118)$

STR. 989-1006

FRANIĆ, R., MIKUŠ, O., GRGIĆ, I.:

POLJOPRIVREDNA...
Poštić već tada govori i o nemogućnosti prelijevanja troškovnih i poreznih opterećenja poljoprivrednika na potrošače. Ovakvo izvanredno vizionarsko razmišljanje ne samo da je doživjelo i svoju potvrdu u razvoju indikatora za mjerenje ovoga prelijevanja (proizvođački subvencijski ekvivalent Franić, 2000.) nego se potvrdilo i formaliziralo u reformama Zajedničke poljoprivredne politike EU-a potkraj 20. stoljeća, kada se osmišljava cijeli niz instrumenata za zaštitu poljoprivrednoga dohotka kojima se ne bi utjecalo na potrošačke (tržišne) cijene proizvoda.

Današnja politička i agrarno-politička retorika naglašavaju potrebu prilagodbe domaćih proizvodnih, trgovinskih i općenito poslovnih standarda europskim i svjetskim standardima. Međutim, Bićanić još 1939. godine govori o potrebi uređivanja zemlje "po uzoru Evrope", a u isto vrijeme upozorava na podređenu ulogu poljoprivrednika koji uživaju slabiju zaštitu od države u odnosu na trgovinu i industriju. Iste rezultate i zaključke nalazimo i u studijama objavljenima šezdeset godina kasnije (Franić, 2000.)!

U suvremenim raspravama o tome što naše poljoprivrednike očekuje u Europskoj uniji traže se odgovori na pitanje što su razlozi razlika domaćih poljoprivrednika u odnosu na europske. Zanimljivi odgovori mogu se naći u djelima iz sredine 20. stoljeća: Mirković još 1950. godine uočava propuste državne politike koja "nema program poljoprivredne politike, pa ga ne može ni provoditi", a Mirković i Stipetić 1960-ih godina sugeriraju i danas prihvatljiva rješenja za probleme seljaka koji su kreditno zaduženi administrativnim i poreznim mjerama u uvjetima gospodarske krize i pod utjecajem svjetskoga tržišta.

Analitičari suvremene agrarne politike naglašavaju kako je u zadnja dva desetljeća politika doživjela zaokret od one usmjerene na poljoprivredu kao djelatnost prema onoj usmjerenoj na razvoj ruralnoga prostora. Ističe se kako je taj zaokret uvjetovan hiperprodukcijom poljoprivrednih proizvoda u zemljama razvijenih zapadnih gospodarstava, visokim izdacima za poljoprivredne potpore ili proširenjem Europske unije, koje je rezultiralo dodatnim pritiskom na poljoprivredni proračun Unije, pa je stoga trebalo osmisliti jednostavnije, jeftinije, a zajednici korisnije programe održavanja vitalnosti ruralnih prostora. Koncepti "suvremene ruralne" politike podrazumijevaju uključenost velikoga broja lokalnih aktera u realizaciji politika, razne ruralne sektore kao korisnike politika, a sve se temelji na održavanju tradicionalnih vrijednosti $i$, naravno, ekonomičnosti ulaganja.

Međutim, prije više od stoljeća, Predavec vrlo jednostavno objašnjava kako se gospodarstvo mora temeljiti na najpo- 
DRUŠ. ISTRAŽ. ZAGREB GOD. 21 (2012) BR. $4(118)$

STR. 989-1006

FRANIĆ, R., MIKUŠ, O., GRGIĆ, I.:

POLJOPRIVREDNA... voljnijem odnosu truda / troška i dobra (danas popularnoj cost-benefit analizi), a suvremenu, vrlo frekventno rabljenu riječ "konkurentnost" tada objašnjava jednostavnim načelima natjecanja. O konkurentnosti seljačkih proizvoda još 1930-ih godina čitamo u Bićanićevim radovima, ali ne samo o tome nego i o potrebi da seljaci zauzmu "aktivnu poziciju u kapitalističkom društvu i ekonomiji" (u današnjoj verziji "novootkriveni" bottom-up pristup), a s posebnom se pozornosti osvrće i na pomoć područjima otežanih uvjeta gospodarenja, načelo naglašeno $\mathrm{u}$ idućem programskom paketu Zajedničke poljoprivredne politike EU-a za razdoblje od 2014. do 2020. godine, ugrađeno i u domaće poljoprivredno zakonodavstvo. Štoviše, spoznaja da treba zaštititi tradicionalne ruralne vrijednosti nije novijega datuma, jer o njoj pišu još potkraj 19. stoljeća Bogišić i Radić, samo što su ondašnji autori to nazivali "seoskim običajima" i "moralnim vrijednostima", a današnji "ruralni razvoj" nekada se jednostavno zvao "napretkom".

Konačno, što možemo zaključiti o evoluciji agrarno-političkih načela, osim da je terminologija osuvremenjena i internacionalizirana? Činjenica je da su se promijenile tehnike analize: prijašnje opisne metode danas su zamijenjene (ili bi trebale biti zamijenjene, jer $\mathrm{u}$ hrvatskoj agrarnoj politici to često i nije tako) egzaktnim ocjenama, a državne mjere trebale bi biti valorizirane priznatim kvantitativnim indikatorima. U skladu sa suvremenim ekonomskim i političkim okolnostima mijenjaju se i ciljevi državnog utjecaja u sektoru poljoprivrede i seoskog/ ruralnog razvoja, a ponešto su se promijenili i instrumenti za ostvarivanje tih ciljeva, tako da tržišno-cjenovnu politiku (zaštitne cijene i visoke carine) sve više zamjenjuju strukturne politike i programi ruralnoga razvoja.

Povijesne okolnosti i ideologije u nas su imale, i još uvijek imaju, veći utjecaj na kreiranje agrarne i ruralne politike od ekonomskih argumenata. I, kao što piše Stipetić (1975.), pojedinačni interesi (poljoprivrede i poljoprivrednoga dohotka, sela i seljaka) podređeni su osnovnom cilju društva. Na teritoriju Hrvatske "osnovni ciljevi društva" drastično su se mijenjali u analiziranom razdoblju. Time se vjerojatno može objasniti i neispunjenje ciljeva postavljenih agrarnom politikom, popraćeno kontinuiranim nezadovoljstvom naših seljaka.

No sudeći po rezultatima i ovoga istraživanja, razloge takva stanja nikako ne bi trebalo tražiti u manjku znanja i svijesti o ulozi poljoprivredne politike $u$ razvoju poljoprivrede i sela. Bez obzira na razdoblje i trenutačne gospodarsko-političke okolnosti, istraživači (autori) uvijek su dobro uočavali agrarno-političke elemente (ciljeve, mjere, instrumente), upozoravali na propuste državne politike i predlagali opcije i ak- 
DRUŠ. ISTRAŽ. ZAGREB GOD. 21 (2012), BR. 4 (118)

STR. 989-1006

FRANIĆ, R., MIKUŠ, O., GRGIĆ, I.

POLJOPRIVREDNA.. cije / rješenja kojima bi se ciljevi postavljeni politikom uspješnije ostvarili u korist poljoprivrede i života ljudi na selu.

Nažalost, čini se da njihove sugestije ni $u$ jednom političkom razdoblju nisu nailazile na razumijevanje službene politike, pa time možemo obrazložiti i promašaje $u$ ostvarivanju rezultata domaće poljoprivrede - $\mathrm{i}$ u prošlosti i u novijem vremenu.

\section{LITERATURA}

Bićanić, R. (1936). Kako živi narod: život u pasivnim krajevima. Zavod za proučavanje seljačkog i narodnog gospodarstva, Zagreb: Gospodarska sloga.

Bićanić, R. (1937). Agrarna kriza u Hrvatskoj 1873-1895. Zagreb, vlastita naklada.

Bićanić, R. (1939). Gospodarska politika. II. izdanje. Zagreb: Štamparija "Grafika" (S. Kovačić).

Bogišić, V. (1867). Naputak za opisivanje pravnijeh običaja, koji živu u narodu. U Beču: Jugoslavenska akademija znanosti i umjetnosti, HAZU, Zagreb.

Brkić, S. i Žutinić, Đ. (2002). Društveni aspekt razvoja seoskih područja. U: Prilagodba Europskoj zajednici hrvatske poljoprivrede, šumarstva i ribarstva (Zbornik) (str. 131-144). Zagreb: HAZU.

Cifrić, I. (1993). Novi socijalni kontekst - novi odnos prema poljoprivredi i okolišu. Sociologija sela, 119/120, 1-9.

Cifrić, I. (2003). Ruralni razvoj i modernizacija: prilozi istraživanju ruralnog identiteta. Zagreb: IDIS.

Defilippis, J. (1993). Upravljanje integralnim razvitkom ruralnih područja. Sociologija sela, 119/120, 35-39.

Defilippis, J. (2005). Poljoprivreda i razvoj. Zagreb: Školska knjiga.

Frangeš, O. (1920). Koje su granice postavljene poljoprivrednoj proizvodnji u Kraljevini SHS. Predavanje na kongresu Glavnog zadružnog saveza u Kraljevini Srba, Hrvata i Slovenaca dne 12. juna 1920. u Zagrebu.

Frangeš, O. (1926). Kriza poljoprivrede u Kralj. SHS. Njezini uzroci i mogućnosti sanacije. Predavanje održano u Glavnom zadružnom savezu u Beogradu, 11. aprila 1926.

Franić, R., Grgić, Z. i Njavro, M. (2004). EU-integracijski pritisak i potraga za 'pravim' akterima tržišnog razvoja poljoprivrede (na primjeru privatizacije Sladorane d.d. Zupanja). Društvena istraživanja, 13(1-2), 49-71.

Franić, R. (2000). Metodologija mjerenja državne intervencije u poljoprivredi Hrvatske. Agriculturae Conspectus Scientificus, 65(2), 79-88.

Franić, R. (2005). Subvencije u hrvatskoj poljoprivredi i prilagodba EU. Zbornik radova Ekonomskog fakulteta u Rijeci. Časopis za ekonomsku teoriju i praksu, 23(1), 133-150.

Franić, R. (2006). Politika ruralnog razvitka - nova prilika za Hrvatsku. Agronomski glasnik, 68(3), 221-235. 
DRUŠ. ISTRAŽ. ZAGREB GOD. 21 (2012) BR. 4 (118),

STR. 989-1006

FRANIĆ, R., MIKUŠ, O., GRGIĆ, I.: POLJOPRIVREDNA...
Franić, R., Žimbrek, T. i Grgić, Z. (2003). Agrarna politika u Republici Hrvatskoj na putu od poljoprivrednoga do održivoga ruralnog razvitka. Društvena istraživanja, 12(6), 1027-1049.

Grahovac, P. (1988). Ciljevi, sredstva, metode i nosioci ekonomske politike. U J. Sirotković i V. Stipetić (Ur.), Ekonomika Jugoslavije, Opći dio (str. 385-408). Informator - Zagreb.

Grahovac, P. (1992). Dugoročne tendencije u međunarodnoj razmjeni poljoprivrednih proizvoda. Agrarno-ekonomske studije, Ekonomika poljoprivrede u suvremenoj Hrvatskoj I. Zbornik radova (str. 7-17). Sveučilište u Zagrebu, Ekonomski fakultet Zagreb.

Grgić, I., Žimbrek, T. i Tratnik, M. (2011a). Čimbenici iseljavanja seoskog pučanstva u Republici Hrvatskoj. Agronomski glasnik, 72(2-3), 143-162.

Grgić, I., Levak, V. i Zrakić, M. (2011b). Zadovoljstvo životom u ruralnom području zagrebačke županije. U S. Košutić (Ur.), Actual Tasks on Agricultural Engineering. Proceedings of the 39th International Symposium on Agricultural Engineering. Opatija 22.-25. veljače (str. 19-28). Sveučilište u Zagrebu, Agronomski fakultet i CIGR, EurAgEng i Asian Association for Agricultural Engineering (AAAE).

Grgić, I., Županac, G. i Zrakić, M. (2011c). Nepoljoprivredne djelatnosti ruralnog područja Zagrebačke županije. U M. Pospišil (Ur.), Proceedings - Abstracts. 46. hrvatski i 6. međunarodni simpozij agronoma. Opatija, 14.-18. veljače (str. 355-359). Sveučilište u Zagrebu, Agronomski fakultet i B.E.N.A., EIA, EurAgEng, ISFAE, ISTRO.

Grgić, I., Zrakić, M. i Cerjak, M. (2011d). Agroturistička ponuda zagrebačke županije: ograničenja i mogućnosti. Agronomski glasnik, 73(1-2), 41-58.

Kumrić, O. i Franić, R. (2008). Kako ocijeniti konkurentnost ruralnog područja? U M. Pospišil (Ur.), Zbornik radova. 43. hrvatski i 3. međunarodni znanstveni simpozij agronoma, Opatija 18.-21. veljače 2008. (str. 215-219). Zagreb, Agronomski fakultet Sveučilišta u Zagrebu, B.EN.A., ISFAE, EIA, ISTRO, EurAgEng.

Mikuš, O. (2010). Ocjenjivanje ruralne konkurentnosti kao podloga kreiranja politike ruralnog razvoja. (Neobjavljena doktorska disertacija). Sveučilište u Zagrebu, Agronomski fakultet, Zagreb.

Mikuš, O., Franić, R. i Grgić, I. (2012). The evaluation of rural competitiveness in creating a policy of rural development in Croatia. Journal of Food, Agriculture \& Environment, 10(2), 132-140.

Mirković, M. (1950a). Ekonomika agrara FNRJ. Zagreb: Nakladni zavod Hrvatske.

Mirković, M. (1950b). O nekim problemima unapređenja agrarne proizvodnje. Zagreb: Zadružna štampa.

Mirković, M. (1952). Seljaci u kapitalizmu. Agrarno-ekonomske studije. Zagreb: Matica hrvatska.

Mirković, M. (1968). Ekonomska historija Jugoslavije. 3. izdanje. Zagreb: Informator

Pokos, N. (2002). Metodologija izdvajanja seoskog stanovništva, njegov raspored i popisne promjene 1953.-2001. U M. Štambuk, I. Rogić i A. Mišetić (Ur.), Prostor iza. Kako modernizacija mijenja hrvatsko selo (str. 31-56). Zagreb: Institut društvenih znanosti Ivo Pilar. 
DRUŠ. ISTRAŽ. ZAGREB GOD. 21 (2012), BR. 4 (118),

STR. 989-1006

FRANIĆ, R., MIKUŠ, O., GRGIĆ, I.: POLJOPRIVREDNA.
Poštić, S. (1926a). Za uređenje cijena šećeru i repi! Štampano kao fragmenat iz rukopisa studije: "Proučavanje seljačkog gospodarstva kao temelj agronomskog rada u narodu". Zagreb: Naklada pisca.

Poštić, S. (1926b). Poresko opteré́enje poljoprivrede i poreska reforma. Zagreb: Udruženje agronoma u Zagrebu.

Predavec, J. (1909). O narodnom gospodarstuu. Zagreb.

Puljiz, V. (1993). Ljudski faktor i ruralni razvitak Hrvatske. Sociologija sela, 31(1/2), 11-16.

Puljiz, V. (1996). Seljaštvo u djelu Rudolfa Bićanića. U I. Bićanić, U. Dujšin i V. Puljiz (Ur.), Rudolf Bićanić: Kako živi narod: život u pasivnim krajevima, Zavod za proučavanje seljačkog i narodnog gospodarstva, Zagreb: Gospodarska sloga.

Radić, A. (1897). Osnova za sabiranje i proučavanje građe o narodnom životu. Zagreb: Tisak Dioničke tiskare.

Roller, D. (1955). Agrarno-proizvodni odnosi na području Dubrovačke Republike od XIII do XV stoljeća. Zagreb: Jugoslavenska akademija znanosti i umjetnosti.

Stipetić, V. (1964). Jugoslavensko tržište poljoprivrednih proizvoda. Beograd: Zadružna knjiga.

Stipetić, V. (1973). Analiza razvoja i strukturnih promjena. Ekonomika Jugoslavije, opći dio. Zagreb: Informator.

Stipetić, V. (1975). Prijeti li glad? Zagreb: Globus.

Štambuk, M. (2002). Selo u europskom iskustvu. U M. Štambuk, I. Rogić i A. Mišetić (Ur.), Prostor iza. Kako modernizacija mijenja hrvatsko selo (str. 361-390). Zagreb: Institut društvenih znanosti Ivo Pilar.

Štambuk, M., Rogić, I. i Mišetić, A. (2002). Prostor iza. Kako modernizacija mijenja hrvatsko selo. Zagreb: Institut društvenih znanosti Ivo Pilar.

Štancl, B. (1964). Utjecaj cijena, premija i regresa na poljoprivrednu proizvodnju. Ekonomika poljoprivrede, XI. (6), jun 1964. Beograd, str. 17-30.

Vichodil, A. (1883). Gospodarska uprava, ili nauka o umnom gospodarenju, dio I Uprava uobće. Zagreb: Tiskara Narodnih Novinah.

Vichodil, A. (1915). Gospodarski radni uredi, njihova zadaća, organizacija i rukovodstvo u državnoj gospodarskoj upravi. Osijek: Hrvatsko-slavonsko gospodarsko društvo.

World Bank (2009). Report No. 478879-HR. CROATIA Croatia's EU Convergence Report: Reaching and Sustaining Higher Rates of Economic Growth (In two volumes) Vol. II: Full Report, June 2009. Europe and Central Asia Region. Document of the World Bank. Posjećeno 12. 3. 2012. na: http://siteresources.worldbank.org/INTCROATIA/Resources/Croatia EUConvergence Report-FullReport.pdf

Žimbrek, T. (1994). Osvrt na politiku cijena i proizvodnih poticaja u poljoprivredi Hrvatske. Gazophylacium, 1(3-4), 294-307.

Žimbrek, T., Grgić, I., Tratnik, M. i Franić, R. (1994). Agrarna politika u Hrvatskoj u području cijena i subvencija. Poljoprioredne aktualnosti, 30(6), 795-806. 
DRUŠ. ISTRAŽ. ZAGREB GOD. 21 (2012) BR. $4(118)$

STR. 989-1006

FRANIĆ, R., MIKUŠ, O., GRGIĆ, I.:

POLJOPRIVREDNA...

\section{Agricultural Policy in Research of Croatian Authors of the 20th Century}

Ramona FRANIĆ, Ornella MIKUŠ, Ivo GRGIĆ

Faculty of Agriculture, Zagreb

The expected Croatian accession to the European Union has once again updated the readiness of our agricultural producers to a market that soon awaits them. Current goals and results of agricultural policy measures are thus being reexamined, but also the policy's development concerning the harmonization of entire rural areas with the Common Agricultural Policy of the EU. The current socio-economic changes haven't significantly altered the main objectives of agricultural policy (providing enough food for consumers at reasonable prices, and an equal standard of living for farmers), but they have just changed the instruments and measures of the states with regard to the economic conditions and political circumstances. In Croatian literature, the farmers' position and life in rural areas have been significantly researched since the mid-nineteenth century. Results of many studies and in particular the given recommendations can still apply. Already in the early years, in many papers, the reasons for different positions of farmers of individual countries were indicated, while papers of the late 20th century emphasize the impossibility of mapping individual solutions from the EU to the Croatian situation.

Keywords: government, village, agriculture, agricultural policy, Croatia 